\title{
Responses of the phytoplankton community in the Yangtze River estuary and adjacent sea areas to the impoundment of the Three Gorges Reservoir
}

\author{
Li Wang ${ }^{1,2}$, Qiuwen Chen ${ }^{1 *}$, Rui Han ${ }^{3}$, Baodong Wang ${ }^{4}$ and Xinwu Tang 5 \\ ${ }^{1}$ Center for Eco-environmental Research, Nanjing Hydraulic Research Institute, Nanjing 210029, China \\ 2 College of Water Conservancy and Hydroelectric Power, Hohai University, Nanjing 210098, China \\ 3 State Key Laboratory of Simulation and Regulation of Water Cycle in River Basin, China Institute of Water Resources and \\ Hydropower Research, Beijing 100038, China \\ 4 The First Institute of Oceanography, Qingdao 266061, China \\ 5 College of Hydraulic and Environmental Engineering, Three Gorges University, Yichang 443002, China
}

Received 15 May 2016; Accepted 27 September 2016

\begin{abstract}
The phytoplankton community in river estuaries is subject to complex physical and chemical stresses. The construction of the Three Gorges Dam (TGD) has dramatically changed the hydroenvironmental conditions, including hydrological regimes and water quality in the Yangtze River estuary (YRE), which could have a significant impact on the estuarine ecosystem. To evaluate the effects of hydroenvironmental alterations on the phytoplankton community in YRE, sampling campaigns were conducted in the area during 2010-2011; meanwhile, historical data before TGD construction and during the TGD filling period were collected. Seasonal variations showed that diatoms dominated the community throughout the sampling period, and the most important environmental factors affecting the phytoplankton community were silicate, total suspended solids and phosphate. With respect to differences in the three phases (before TGD construction, during TGD filling and after TGD filing), the abundance of phytoplankton showed an increasing trend: the proportions of diatom species numbers declined, while the proportions of Dinophyta species numbers increased. The position of phytoplankton abundance maximum moved inwards to the estuary of the Yangtze River after the impoundment of the TGD.
\end{abstract}

Key words: Phytoplankton / anthropogenic influence / long-term changes / Yangtze River estuary / Three Gorges Dam

\section{Introduction}

Phytoplankton is the link between the abiotic and the biotic compartments of ecosystems (Büsing, 1998; DíazPardo et al., 1998; Klausmeier et al., 2008). As the basis of the food chain and the pathways for carbon and energy fluxes, phytoplankton plays an important role in marine ecosystems (Smayda, 1997; Fu et al., 2009). The short lifespan and the ability to produce resting stages make phytoplankton sensitive to hydro-climatic changes (Guerrero and Rodriguez, 1998; McQuoid et al., 2002). Phytoplankton are therefore often used as indicators of environmental changes (Beaugrand, 2005). In recent decades, algal blooms caused by human activities have

\footnotetext{
*Corresponding author: qwchen@nhri.cn
}

become a global phenomenon that impacts many coastal nations in the world (Hallegraeff, 1993; Da Costa et al., 2002, 2005; Verity, 2010).

Situated at the interface between the continental and oceanic domains, estuaries are subject to frequent and significant environmental changes. In particular, the chemical composition of estuarine waters is determined by the highly variable fluvial flows (Lam-Hoai et al., 2006). Over the past 50 years, fluvial flow patterns and sediment have been highly modified by river dams (Dai and Liu, 2013; Dhivert et al., 2015). It is reported that more than 45000 large dams have been constructed around the world. China ranks first with 22265 , with a percentage of $44.80 \%$ (Chen et al., 2011a). Consequently, around 70\% of the world's rivers are intercepted by large reservoirs (Kummu and Varis, 2007). These changes in the river flow regime can lead to alterations in the diversity of fauna 
and flora, and affect the downstream ecosystem (Li et al., 2010; Chen et al., 2011b; Haghighi et al., 2014). For instance, due to surplus of nutrients in the Egyptian coastal waters before the impoundment of the Aswan High Dam, algal blooms often burst out which supported a rich fishery (El Bastawesy et al., 2014). With over $90 \%$ decrease in freshwater runoff, the phytoplankton bloom disappeared and the fisheries collapsed. Along the Mississippi River, a large number of dams and bank protection projects have led to a dramatic decrease in flooding and flux of sediment to downstream areas (Milliman, 1997), resulting in a rapid loss of coastal land by the expansion of lagoons. In general, dam construction usually slows water velocity, prolongs water residence time (Friedl and Wüest, 2002), and finally influences the structure of the aquatic ecosystem (Zhao et al., 2010).

The Three Gorges Dam (TGD) in the Yangtze River is the world's largest hydroelectric project. The TGD began in 1993 and was completed in 2009 (CWRC, 1997). The whole impoundment plan can be divided into three stages. The TGD began to store water in June 2003, and the water level reached $135 \mathrm{~m}$ above sea level. The second phase was completed with the water level reaching $156 \mathrm{~m}$ in October 2006. The third phase was finished in 2008, when the water level reached to $175 \mathrm{~m}$. After impoundment, the TGD has been operated in the mode of "storing clear and releasing muddy", which caused a great difference between the water residence times within a year (Xu et al., 2009). The dramatic change of the hydrological regime has caused severe ecological problems in the estuary (Domingues et al., 2014). Analysis of phytoplankton community structural changes can be more insightful than merely using geochemical parameters in detecting hydroenvironmental disturbance.

In this context, it was assumed that the phytoplankton in the YRE and adjacent areas were spatially and temporally altered in abundance and community composition during TGD construction. To test this hypothesis, three field surveys were conducted in 2010 and 2011, and other investigations covering different phases related to TGD construction were collected. The data were analyzed with specific objectives to: (1) understand the composition and structure of the phytoplankton community over space; (2) identify the most important hydro-environmental variables affecting the distribution of phytoplankton species; and (3) evaluate the effects of the TGD on phytoplankton community structure in the three phases of TGD construction.

\section{Materials and methods}

\section{Study area}

The YRE and adjacent sea areas (Fig. 1) are located in the center of the Chinese eastern coast. The estuary and adjacent coastal waters are mainly affected by freshwater runoff from the Yangtze River, the coastal currents along Mainland China (East China Sea Coastal Current,

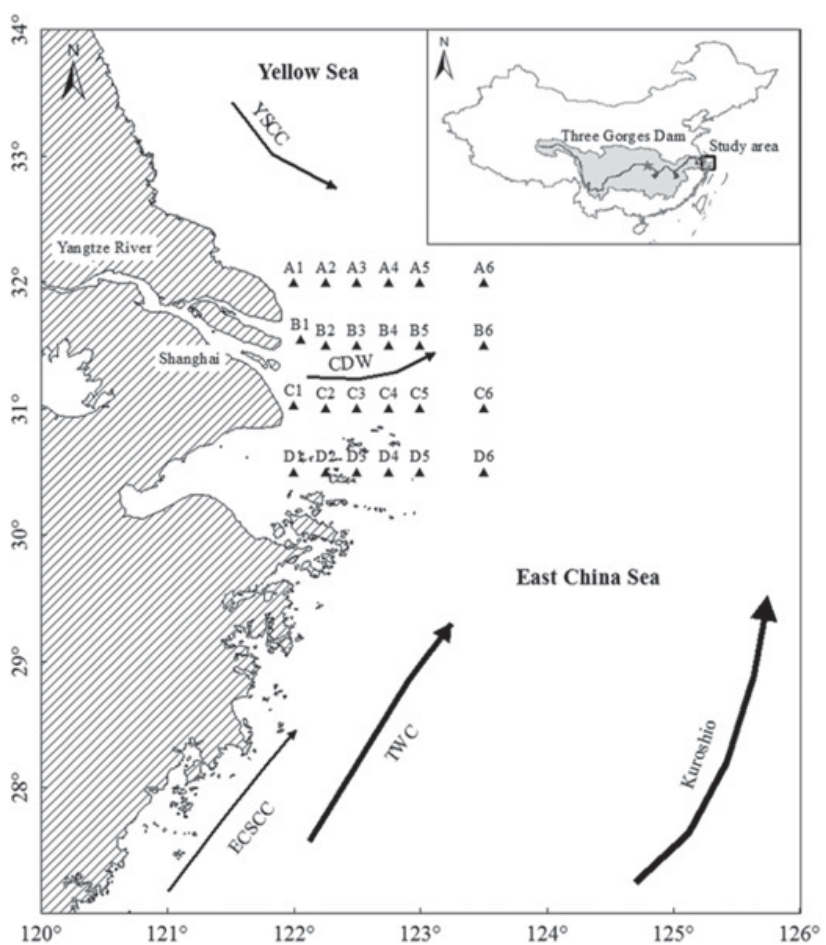

Fig. 1. Study area and sampling stations in the YRE and adjacent sea areas. Each dot represents a survey station. The survey was conducted in August 2010, November 2010 and May 2011. YSCC, Yellow Sea Coastal Current; YRDW, Yangtze River Diluted Water; ECSCC, East China Sea Coastal Current; TWC, Taiwan Warm Current.

ECSCC; Yellow Sea Coast Current, YSCC), the Taiwan Warm Current (TWC) from the Taiwan Strait, and a branch of the Kuroshio Current extending into the area from Northeast Taiwan (Lü et al., 2006; Zhou et al., 2008; Jiang et al., 2015). The outflow of the Yangtze River provides high levels of nutrients (e.g., N, P and $\mathrm{Si}$ ) and other biogenic elements to the YRE and adjacent coastal waters (Jiang et al., 2015). The annual discharge of the Yangtze River showed little variation from 1959 with an average of $2.8 \times 10^{4} \mathrm{~m}^{3} \cdot \mathrm{s}^{-1}$ (Fig. 2). Sediment discharge and concentration decreased significantly in past decades (Feng et al., 2014). The Yangtze River basin, especially the lower reaches and the estuarine area, is characterized by high industrialization and urbanization. The nitrogen and phosphorus load in the YRE has increased approximately seven- to eightfolds since 1960 (Shen, 2001; Chen et al., $2011 \mathrm{a}, \mathrm{b}$ ); however, the dissolved Si concentration decreased gradually after TGD impoundment (Chai et al., 2009).

\section{Sampling and laboratory procedures}

Phytoplankton and environmental data were collected from 24 stations in August 2010 (high-flow in summer), November 2010 (low-flow in autumn) and May 2011 

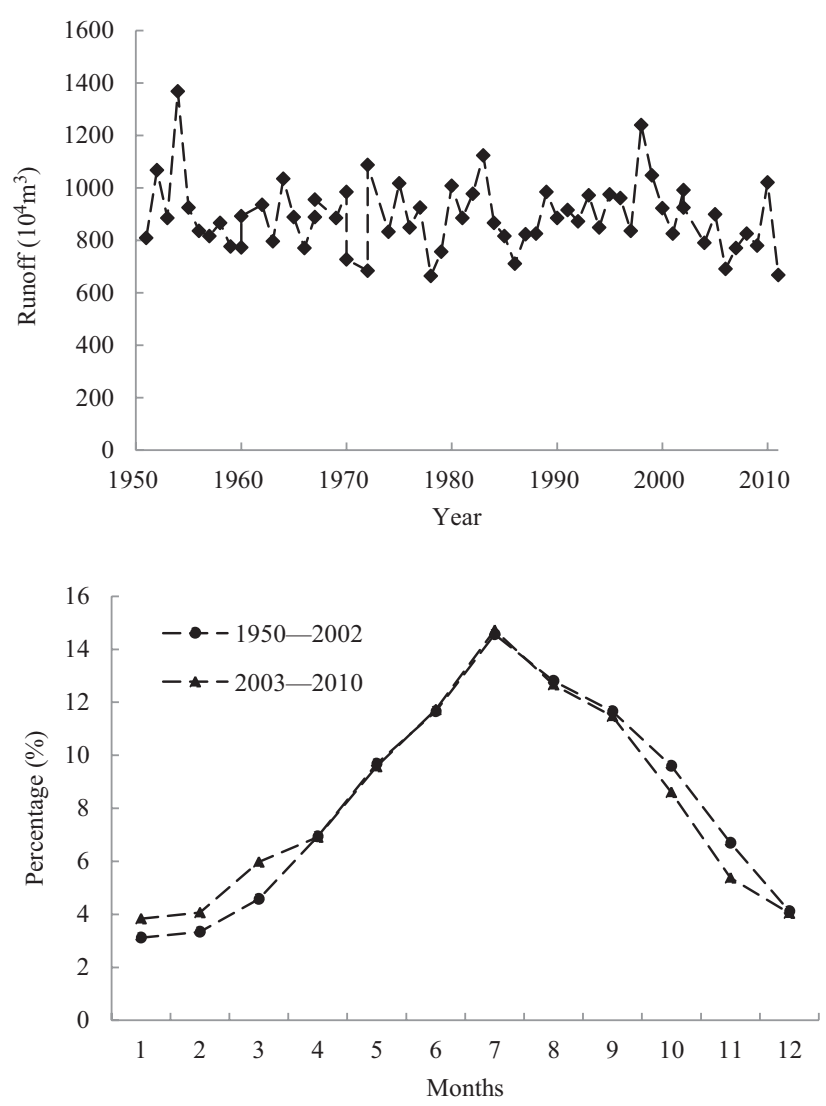

Fig. 2. Variation of annual and monthly runoff at the Datong station before and after the impoundment of the TGD. Percentage is the value that each months' runoff accounts for in water discharge throughout the year. (Data source: http:// www.cjw.gov.cn)

(normal-flow in spring). The sampling sites are illustrated in Figure 1.

At each site, three water samples were collected from the surface $(0.2 \mathrm{~m}$ below water surface $)$, middle and bottom ( $0.2 \mathrm{~m}$ above sea bed) of the water column. Water temperature, salinity and $\mathrm{pH}$ were measured in situ with a CTD instrument (CTD $90 \mathrm{M}$, Germany). Water samples were collected using 5.0 L Nisk water samplers, and were stored in a portable refrigerator at $<4^{\circ} \mathrm{C}$. Water samples for dissolved inorganic nitrogen $(\mathrm{DIN}=$ nitrate $\left(\mathrm{NO}_{3}-\mathrm{N}\right)+$ nitrite $\left(\mathrm{NO}_{2}-\mathrm{N}\right)+$ ammonium $\left.\left(\mathrm{NH}_{4}-\mathrm{N}\right)\right)$, phosphate $\left(\mathrm{PO}_{4}-\mathrm{P}\right)$ and silicate $\left(\mathrm{SiO}_{3}-\mathrm{Si}\right)$ analyses were filtered through a $0.45 \mu \mathrm{m}$ cellulose acetate filter. Nutrient concentration analyses were performed by a continuous-flow analyzer (Skalar San ++ , Netherlands) with colorimetric methods described by Grasshoff et al. (1999) and Zhang et al. (1997). To determine total suspended solids (TSS), a known volume of the wellmixed sample was filtered through a dried and preweighed membrane filter with a pore size of $0.45 \mu \mathrm{m}$. The dry mass of the particulate materials captured in each filter was calculated by subtracting the filter mass from the dried mass.
Field sampling and laboratory analysis of phytoplankton were conducted according to the Specifications for Oceanographic Survey (State Oceanic Administration, 1991). The sedimentation method was used for individual counting and species identification (Utermöhl, 1958). Samples for phytoplankton analysis were fixed with buffered formaldehyde to obtain a final concentration of $2.5 \%$ and stored in the 1-L dark bottles. In the laboratory, phytoplankton was identified to the species level when possible, and abundance enumerated using an inverted microscope (Nikon TS100). Taxonomic identification of phytoplankton species was done according to Tomas (1997) and Priddle and Fryxell (1985). At least 400 units (individual cells) for each sample were counted.

\section{Historical data collection}

The historical data of phytoplankton corresponding to the three phases of the TGD were collected from the First Institute of Oceanography, Qingdao, China. The data in 1959 were considered as the conditions of reference. The Three Gorges floodgates were closed in 2003 and the dam attained its maximum level by the end of 2008; the data in 2006 thus correspond to the damfilling phase. The water level reached up to $175 \mathrm{~m}$, so the data during 2010-2011 represent the post-filling situation. The sampling sites in 1959 and in 2006 are shown in Figure 3.

\section{Date analysis method}

Relations between phytoplankton and hydro-environmental factors: Biota-Environment (BIOENV, Primer 5) was used to investigate the relationship between the phytoplankton assemblage and hydro-environmental factors, and their Spearman correlation coefficients were calculated. BIOENV selects environmental variables that can best explain the phytoplankton assemblage patterns, by maximizing the rank correlation with the phytoplankton assemblage similarity matrices. The population abundance data were transformed into $\log (x+1)$ to balance the contributions from the few "very abundant species" with the many "rare species" (Clarke and Warwick, 2001).

To test for differences in the species composition of phytoplankton communities in the different phases of TGD construction, a one-way analysis of similarities (ANOSIM, Primer 5) was performed across 1959, 2006 and 2010. A distance matrix was obtained based on BrayCurtis dissimilarities (Bray and Curtis 1957) and tested for differences between groups. In this study, $R$-values higher than 0.5 were considered as clear differences between groups, and the significance level was set to 0.01 . The population abundance data were also transformed into $\log (x+1)$ to balance the contributions from the few "very abundant species" with the many "rare species" (Clarke and Warwick, 2001). 

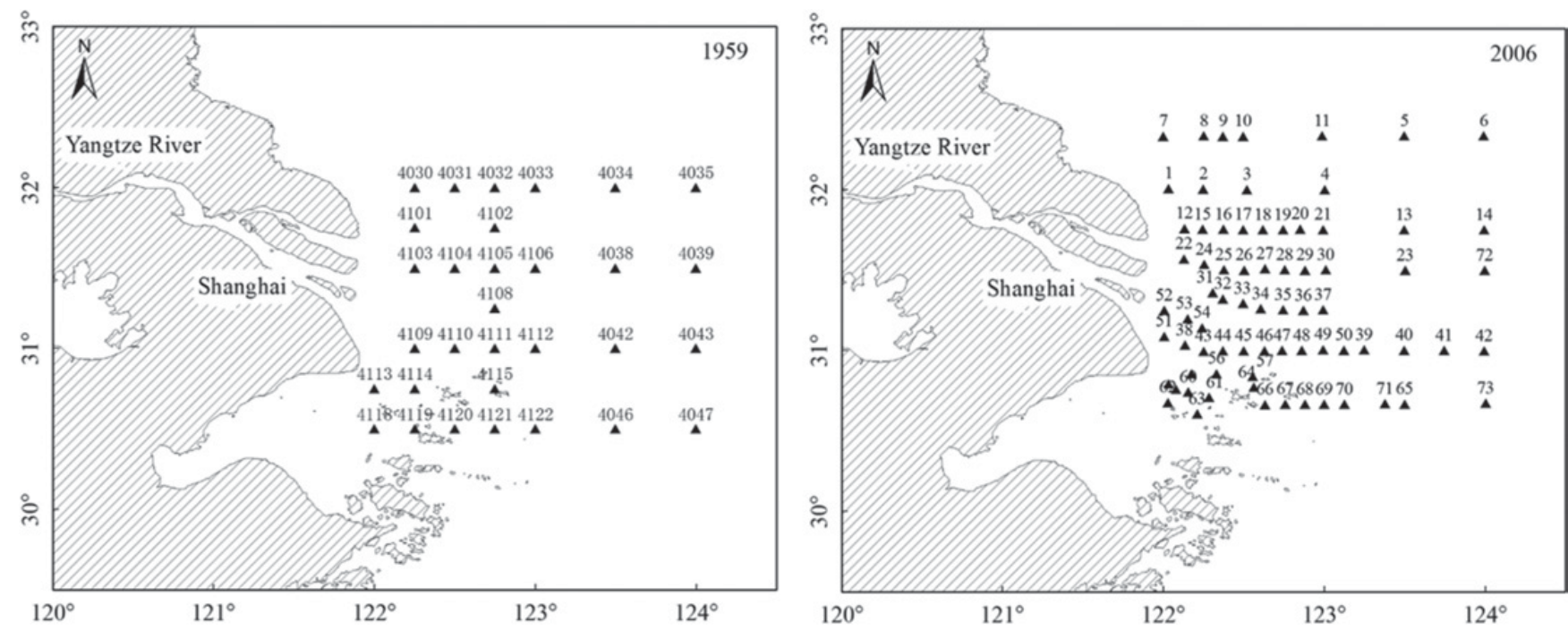

Fig. 3. Study area and sampling stations in the YRE. Each dot represents a survey station. The surveys were conducted in 1959 (left) and in 2006 (right).

Table 1. Dominant species and dominance index of phytoplankton in YRE.

\begin{tabular}{|c|c|c|c|c|}
\hline Season & Number & Dominant species & Abundance $\left(10^{4}\right.$ cell. $\left.\mathrm{m}^{-3}\right)$ & $\overline{\text { Dominance }}$ \\
\hline \multirow[t]{4}{*}{ Spring } & 1 & Skeletonema costatum & 8.36 & 0.4931 \\
\hline & 2 & Noctiluca scintillans & 1.64 & 0.0886 \\
\hline & 3 & Coscinodiscus asteromphalus & 11.53 & 0.0425 \\
\hline & 4 & Coscinodiscus spinosus & 0.72 & 0.0103 \\
\hline \multirow[t]{5}{*}{ Summer } & 1 & Skeletonema costatum & 2400.02 & 1.7802 \\
\hline & 2 & Chaetoceros affinis & 359.75 & 0.2379 \\
\hline & 3 & Pseudo-nitzschia sp. & 3878.98 & 0.1475 \\
\hline & 4 & Chaetoceros sp. & 277.07 & 0.0320 \\
\hline & 5 & Rhizosolenia alata f. indica & 39.38 & 0.0277 \\
\hline \multirow[t]{3}{*}{ Autumn } & 1 & Thalassionema frauenfeldii & 846.33 & 0.1843 \\
\hline & 2 & Skeletonema costatum & 461.7 & 0.0555 \\
\hline & 3 & Bacteriastrum hyalinum & 194.11 & 0.0269 \\
\hline
\end{tabular}

The value of population abundance is the average of the study area.

\section{Results}

\section{Phytoplankton community at present}

A total of 96 phytoplankton species belonging to four phyla were collected during the three sampling seasons in 2010-2011, including Bacillariophyta, Dinophyta, Cyanophyta and Chrysophyta. The phytoplankton consisted mainly of two groups: Diatoms and Dinoflagellates. Diatoms represented the dominant group in all the three sampling seasons. In spring, 43 species were identified, including 27 Bacillariophyta, 15 Dinophyta and one other taxonomic species. In summer, there were 44 species of Bacillariophyta and 16 species of Dinophyta. In autumn, 60 species were identified, including 41 species of Bacillariophyta, 16 species of Dinophyta and three other taxonomic species. The dominant phytoplankton species changed over time (Table 1). Four dominant species in spring, five in summer and three in autumn were identified. The three seasons shared no common dominant species except Skeletonema costatum.

Evident variations of phytoplankton abundance were observed both in seasons and in space (Fig. 4). The average abundance of phytoplankton was $12.72 \times 10^{4}$, $3755.67 \times 10^{4}$ and $1578.93 \times 10^{4}$ cell.m $^{-3}$ in spring, summer and autumn, respectively. In spring, the maximum abundance appeared at A5 and $\mathrm{C} 3$, which were outside of the mouth (Fig. 4). In summer, the abundance was higher in the north of the estuary than in the south. In autumn, the area near Zhoushan Island had the highest abundance (Fig. 4).

\section{Phytoplankton distribution in relation to hydro-environmental features}

BIOENV (Table 2) showed that the combination of surface layer $\mathrm{SiO}_{3}-\mathrm{Si}$ and surface layer $\mathrm{PO}_{4}-\mathrm{P}$ could explain the highest percentage of phytoplankton variation 

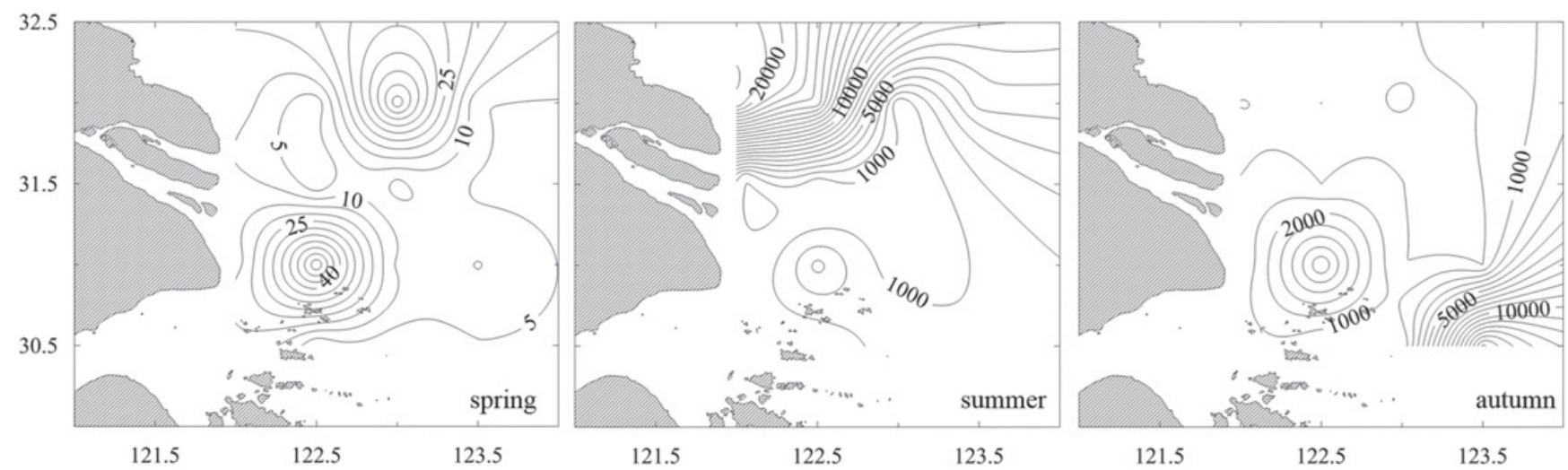

Fig. 4. Spatial distribution of phytoplankton abundance in the YRE in spring of 2011, summer and autumn of 2010 (Abundance: $10^{4}$ cell. $\left.\mathrm{m}^{-3}\right)$.

Table 2. Relationships between phytoplankton abundance and environmental variables.

\begin{tabular}{llc}
\hline Season & \multicolumn{1}{c}{ Governing factor } & $\begin{array}{c}\text { Correlation } \\
\text { coefficient }\end{array}$ \\
\hline Spring & $\mathrm{SiO}_{3}-\mathrm{Si}\left(\mathrm{s}^{*}\right) / \mathrm{PO}_{4}-\mathrm{P}\left(\mathrm{s}^{*}\right)$ & 0.922 \\
& $\mathrm{SiO}_{3}-\mathrm{Si}(\mathrm{s}) / \mathrm{PO}_{4}-\mathrm{P}(\mathrm{m})$ & 0.922 \\
& $\mathrm{SiO}_{3}-\mathrm{Si}(\mathrm{m}) / \mathrm{PO}_{4}-\mathrm{P}\left(\mathrm{m}^{*}\right) / \mathrm{DIN}(\mathrm{s})$ & 0.921 \\
\multirow{3}{*}{ Summer } & $\mathrm{TSS}(\mathrm{s}) / \mathrm{SiO}_{3}-\mathrm{Si}(\mathrm{s}) / \mathrm{SiO}_{3}-\mathrm{Si}(\mathrm{m})$ & 0.648 \\
& $\mathrm{TSS}(\mathrm{m}) / \mathrm{SiO}_{3}-\mathrm{Si}(\mathrm{b})$ & 0.641 \\
& $\mathrm{TSS}(\mathrm{s}) / \mathrm{SiO}_{3}-\mathrm{Si}(\mathrm{b}) / \mathrm{Temp}(\mathrm{m})$ & 0.639 \\
Autumn & $\mathrm{TSS}(\mathrm{s})$ & 0.532 \\
& $\mathrm{TSS}(\mathrm{m}) / \mathrm{Sal}(\mathrm{b})$ & 0.522 \\
& $\mathrm{TSS}(\mathrm{s}) / \mathrm{TSS}(\mathrm{m})$ & 0.510 \\
\hline
\end{tabular}

*: $\mathrm{s}=$ surface layer; $\mathrm{m}=$ middle layer; $\mathrm{b}=$ bottom layer. $\mathrm{SiO}_{3}-\mathrm{Si}$, $\mathrm{PO}_{4}-\mathrm{P}, \mathrm{DIN}, \mathrm{TSS}, \mathrm{Temp}$ and Sal represent silicate, phosphate, dissolved inorganic nitrogen, total suspended solids, temperature and salinity, respectively.

in spring. In summer, phytoplankton assemblages were best associated with the surface layer TSS, surface layer $\mathrm{SiO}_{3}-\mathrm{Si}$ and middle layer $\mathrm{SiO}_{3}-\mathrm{Si}$, with a maximum correlation coefficient of 0.648 . In autumn, the surface layer TSS could explain $53.2 \%$ of phytoplankton variations.

According to the above result, it was obvious that the distribution of surface layer TSS, $\mathrm{SiO}_{3}-\mathrm{Si}$ and $\mathrm{PO}_{4}-\mathrm{P}$ were crucial to phytoplankton assemblages. To this end, their spatial variations were shown in Figure 5. For the surface layer TSS, it could be up to $400 \mathrm{NTU}$ in the inshore region and was quickly reduced to $<10 \mathrm{NTU}$ along $123^{\circ} \mathrm{E}$ (Fig. 5) with the same distribution pattern among the three seasons. The average value of TSS in summer was highest $(69.03 \pm 105.71 \mathrm{NTU})$ in comparison with spring $(40.54 \pm 59.32 \mathrm{NTU})$ and autumn $(42.05 \pm 55.64 \mathrm{NTU})$. With respect to nutrients, surface $\mathrm{PO}_{4}-\mathrm{P}$ in spring, summer and autumn in the whole investigation averaged $1.27 \pm 0.68,1.75 \pm 0.76$ and $1.45 \pm 0.63 \mu \mathrm{M}$, and $\mathrm{SiO}_{3}$ was $13.87 \pm 8.97,19.74 \pm 17.2$ and $14.58 \pm 13.1 \mu \mathrm{M}$, respectively. Surface $\mathrm{PO}_{4}-\mathrm{P}$ and $\mathrm{SiO}_{3}$ generally decreased seawards, following the pattern of Yangtze River diluted water (Fig. 5).

\section{Comparisons of phytoplankton variation in the three phases}

Diatoms dominated the community in the three phases of TGD construction (Table 3), accounting for $83 \%$ in $1959,61 \%$ in 2006 and $73 \%$ in 2010 , respectively. However, the proportions of diatom species numbers declined, while the proportions of Dinoflagellates species numbers increased. In terms of spatial distribution of phytoplankton abundance, it exhibited the same pattern during the three phases. Two obvious peaks were identified in the three phases: the first appeared in the north of the estuary, and the second appeared in the west of Zhoushan Island (Fig. 6). Mean phytoplankton abundance in the study area reached a maximum in the filling period, with a value of $7.3 \pm 0.7 \times 10^{7}$ cell.m $^{-3}$ (Table 3).

The ANOSIM results of statistical dissimilarity in three phases showed that there was no significant composition dissimilarity in the global comparison across 1959, 2006 and 2010 (global $R=0.042, \quad P>0.01, \quad$ ANOSIM). However, phytoplankton community structure in 1959 was significantly different from that in $2010(R=0.503$, $P<0.01$, ANOSIM). Little difference in community structure was observed between 2006 and 1959 ( $R=-0.021, P>0.01$, ANOSIM), and a slight difference was confirmed between 2006 and $2010(R=0.148$, $P>0.01$, ANOSIM).

\section{Discussion}

\section{Dominant species of phytoplankton and their spatial distribution}

S. costatum and Noctiluca scintillans in spring and $S$. costatum in summer were the absolute dominant species. They were the species that were reported to be the main red tide causative agents in the vicinity of the YRE in recent years (Zhao et al., 2009; Li et al., 2014). It was reported that $S$. costatum blooms often occurred following $N$. scintillans blooms in the YRE (Shen and 

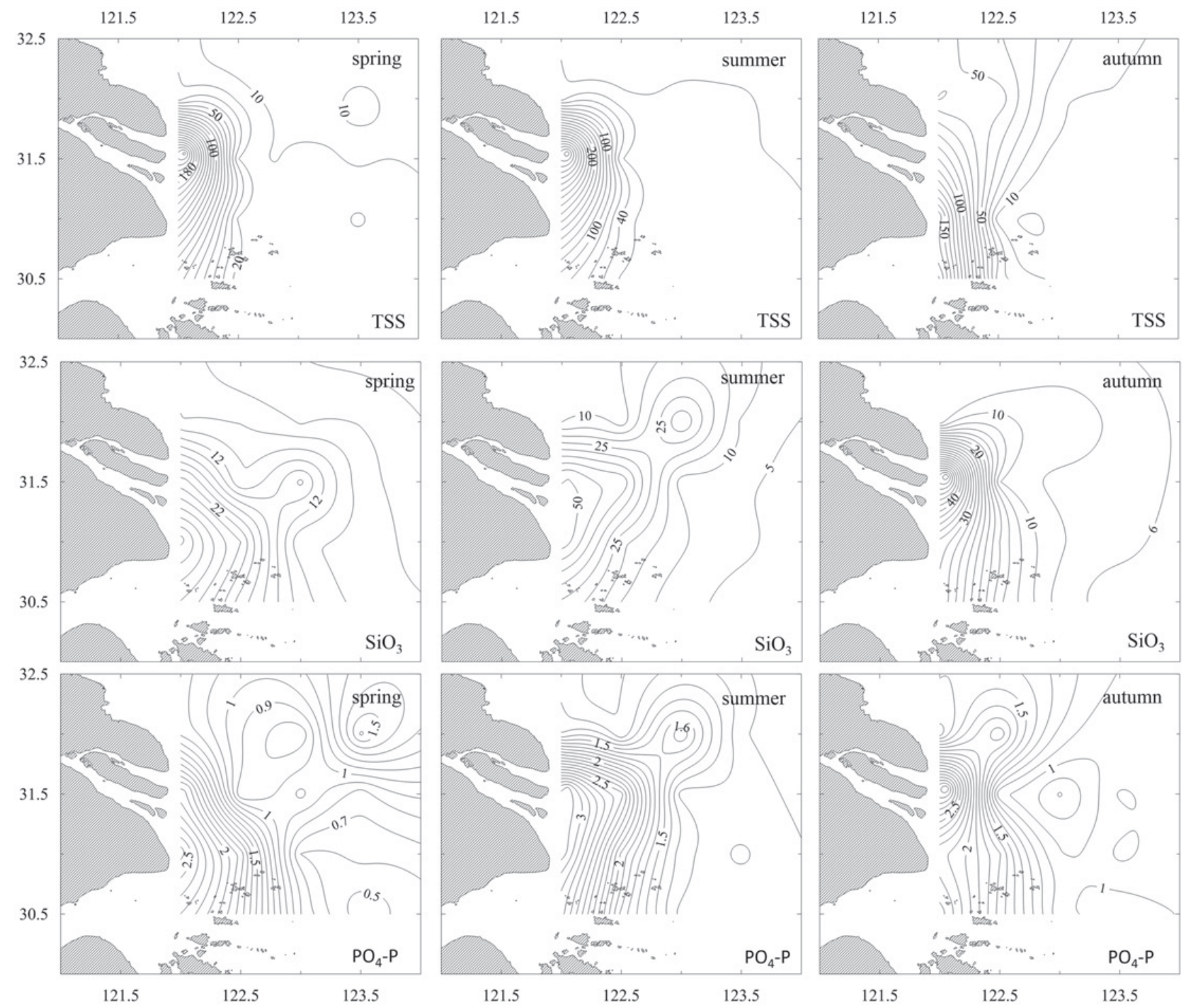

Fig. 5. Spatial distribution of surface layer TSS, $\mathrm{SiO}_{3}-\mathrm{Si}$ and $\mathrm{PO}_{4}-\mathrm{P}$ in the YRE in spring of 2011, summer and autumn of 2010 (TSS: NTU; $\left.\mathrm{SiO}_{3}-\mathrm{Si}: \mu \mathrm{M} ; \mathrm{PO}_{4}-\mathrm{P}: \mu \mathrm{M}\right)$.

Table 3. Number of species of phytoplankton groups and average population abundance in the three phases (1959: prefilling; 2006: filling; 2010: post-filing).

\begin{tabular}{lccc}
\hline The landmark phase & 1959 & 2006 & 2010 \\
\hline Bacillariophyta & 24 & 148 & 44 \\
Dinophyta & 3 & 60 & 16 \\
Other groups & 2 & 34 & 0 \\
Sample site & 30 & 73 & 24 \\
Sample time & 1959.08 & 2006.08 & 2010.08 \\
Population abundance & 2023.32 & 7336.39 & 3755.67 \\
$\left(10^{4} \text { cell. }^{-3}\right)^{*}$ & & &
\end{tabular}

*The value of population abundance is the average of the investigated area in the three phases.

Hong, 1994). Harmful algal blooms (HABs) frequently occur in a region bounded by $28.0^{\circ}-31.5^{\circ} \mathrm{N}$ and $121.5^{\circ}-123.5^{\circ} \mathrm{E}$ in April-August (Liu et al., 2013). In this study, the abundance of $S$. costatum reached a maximum of $58.33 \times 10^{4}$ cell.m $\mathrm{m}^{-3}$ in spring and $2.09 \times 10^{8}$ cell. $\mathrm{m}^{-3}$ in summer. It was observed that, in summer, the abundance of $S$. costatum in some locations exceeded the standard of $\mathrm{HAB}$ formation $\left(5 \times 10^{6}\right.$ cell.m $\left.{ }^{-3}\right)$ (Wang, 2002). The peak value of $N$. scintillans appeared in spring, which was $11.12 \times 10^{4}$ cell. $\mathrm{m}^{-3}$.

With respect to the spatial distribution of phytoplankton, it was observed that the high abundance area of phytoplankton overlapped with the location of Yangtze River dilution water. The region affected by freshwater discharge is generally confined to the area west of $123^{\circ} \mathrm{E}$, bordered by the TWC in the offshore area, where the maximum abundance of phytoplankton often appeared. This phenomenon could be explained by the fact that diatom distribution determined the spatial distribution of phytoplankton due to their absolute dominance in the 

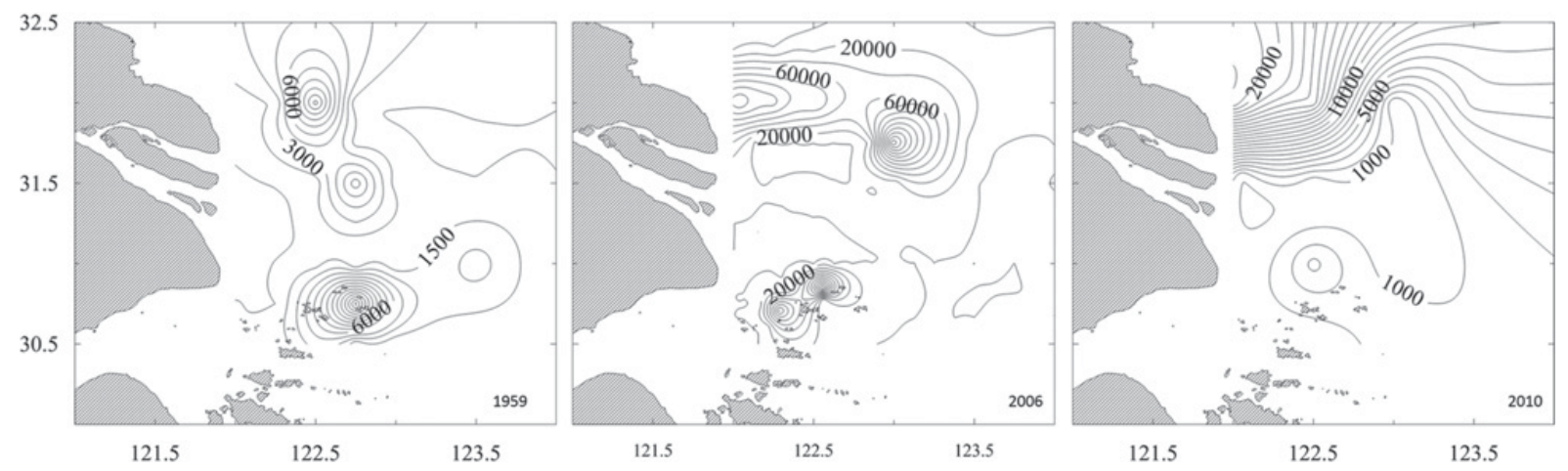

Fig. 6. Distribution of phytoplankton abundance in the three phases (1959: prefilling; 2006: filling; 2010: post-filing). The data for all three phases were collected in summer (Abundance: $10^{4}$ cell. $\mathrm{m}^{-3}$ ).

phytoplankton community structure, and diatoms were significantly affected by the freshwater from the Yangtze River (Zhou et al., 2008). The maximum abundance area of diatoms appeared in salinity ranging from 14 to 23 , and temperature ranging from 20 to $28^{\circ} \mathrm{C}$, which agreed with the tongue region of Yangtze diluted water.

\section{Relations to hydro-environmental factors}

TSS was found to be an important factor affecting phytoplankton distribution in the YRE. Estuarine phytoplankton growth is basically regulated by nutrient and light availability, which in turn depends on freshwater flow. Reduced river discharges usually boost phytoplankton growth by allowing an increase in water residence time and a decrease in turbidity, which leads to increased light availability (Butrón et al., 2009; Morais et al., 2009). The study area was in the location of maximum turbidity, so the phytoplankton in the YRE suffered from severe light limitation. After the impoundment of the TGD, the annual sediment inflow into the estuary decreased by almost 70\% (Dai et al., 2014). Consequently, turbidity was reduced and light penetration enhanced, thus promoting primary production in the YRE (Jiang et al., 2014). In particular, the TGD changed the discharge pattern of the Yangtze River, such that the flow downstream of the TGD increased in spring and decreased in autumn (Chai et al., 2009). The decrease of salinity in spring facilitated the growth of low-salt species (e.g., S. costatum and $N$. scintillans). It was reported that red tides occurred frequently in the YRE and nearby areas, and most of them appeared in spring (Gao and Song, 2005; Zhou et al., 2008).

Nutrients were found to be another important factor in the distribution of phytoplankton in the YRE. The variability of nutrient inputs to estuaries and coastal zones after river impoundment is somewhat unpredictable and depends not only on changes in river flow, but also on human activities that may be enhanced due to damming (Domingues et al., 2014). The result showed that there was high correlation between silicate and the distribution of phytoplankton in spring and summer. This was easy to understand because diatoms dominated the phytoplankton community in spring and summer. Another nutrient factor based on BIOENV was phosphorus, as phosphorus limitation was observed in the YRE (Zhou et al., 2008; Chai et al., 2009). Therefore, the interception of silicate and phosphorus by the TGD had already and would further change the nutrient structure (nitrogen/silicate and nitrogen/phosphorus ratios) and thus affect the phytoplankton community in the YRE.

\section{Variation of phytoplankton during the three phases}

The shift of phytoplankton community composition toward non-siliceous species is typical after river impoundment and has been observed in many rivers, estuaries and adjacent coastal zones, such as the Danube River and the Black Sea (Humborg et al., 1997), the Nile River and the Eastern Mediterranean Sea (Turley, 1999). After the construction of the TGD, proportions of Bacillariophyta species decreased from $82.76 \%$ in the prefilling phase to $73.33 \%$ after dam filling, mainly due to the decline of dissolved $\mathrm{Si}$ concentrations. Diatoms are considered "healthy" for the ecosystem, and benefit a diatomzooplankton-fish food web. The decline of diatom biomass can thus pose serious consequences for upper trophic levels (Beaugrand and Kirby, 2010). According to the results of ANOSIM, significant alterations in phytoplankton community structure were observed between 1959 and 2010. These suggest that the construction of the TGD had effects on the phytoplankton community structure.

Another response of the phytoplankton community to the construction of the dam in this region was the change in the position of the phytoplankton abundance maximum. Figure 6 shows that phytoplankton abundance increased during the filling (2006) and post-filling (2010) periods. It was found that the position of the phytoplankton biomass maximum moved inwards to the estuary of the Yangtze River after the impoundment of the TGD. Many studies indicate that the limitation of phosphorus and light are common characteristics of estuaries ( $\mathrm{Pu}$ et al., 2001; Ning et al., 2004). The ecosystems of the Yangtze 
River estuary (YRE) and adjacent coastal waters were driven by the nutrient-rich freshwater from the Yangtze River. The concentration of nutrients, such as phosphate, decreased from inside to outside of the YRE (Chai et al., 2009). In addition, light attenuation in coastal ecosystems was strongly dependent on the concentration of suspended particulate matter (Feng et al., 2014), and consequently sediment trapping promoted an increase in light availability. Therefore, the maximum of phytoplankton moved inwards to the estuary due to the interception of sediment after TGD impoundment.

\section{Conclusions}

After the TGD impoundment, the phytoplankton community structure and spatial distribution in the YRE showed obvious changes, due to the interception of sediment and alteration of discharge by the TGD. The environmental indicative variables for the TGD impoundment effects on YRE phytoplankton community were TSS and the silicate/phosphorus/nitrogen ratio. The changes in the salinity profile due to alteration of river discharge affected the temporal variations of the phytoplankton community.

Acknowledgements. The authors are grateful to the funding from the National Natural Science Foundation of China (Grant numbers 51425902 and 91547206) and National Basic Research Program 973 (Grant number 2010CB429004). Special thanks go to Dr Sun X. and Xin M. for assistance with the fieldwork and laboratory analyses. We thank Dr Catherine Rice from the USA for proofreading the English.

\section{References}

Beaugrand G., 2005. Monitoring pelagic ecosystems using plankton indicators. ICES J. Mar. Sci., 62, 333-338.

Beaugrand G. and Kirby R.R., 2010. Climate, plankton and cod. Glob.l Change Biol., 16, 268-1280.

Bray R.J. and Curtis J.I., 1957. An ordination of the upland forest communities of southern Wisconsin. Ecol. Monogr., 27, 325-349.

Büsing N., 1998. Seasonality of Phytoplankton as an Indicator of Trophic Status of the Large Perialpine 'Lago di Garda'. Phytoplankton and Trophic Gradients, Springer, Netherlands, 153-162.

Butrón A., Iriarte A. and Madariaga I., 2009. Sizefractionated phytoplankton biomass, primary production and respiration in the Nervión-Ibaizabal estuary: a comparison with other nearshore coastal and estuarine ecosystems from the Bay of Biscay. Cont. Shelf Res., 29, 1088-1102.

Chai C., Yu Z., Shen Z., Song X., Cao X. and Yao Y., 2009. Nutrient characteristics in the Yangtze River estuary and the adjacent East China Sea before and after impoundment of the Three Gorges Dam. Sci. Total Environ., 407, 4687-4695.
Changjiang Water Resource Commission (CWRC), 1997. Study on Eco-environmental Impacts of Three Gorges Project, Hubei Science and Technology Press, Wuhan, China (in Chinese).

Chen S., Chen B. and Su M., 2011a. An estimation of ecological risk after dam construction in LRGR, China: changes on heavy metal pollution and plant distribution. Proc. Environ. Sci., 5, 153-159.

Chen Y.X., Liu R.M., Sun C.C., Zhang P.P., Feng C.H. and Shen Z.Y., 2011b. Spatial and temporal variations in nitrogen and phosphorous nutrients in the Yangtze River Estuary. Mar. Pollut. Bull. 64, 2083-2089.

Clarke K.R. and Warwick R.M., 2001. Changes in Marine Communities: An Approach to Statistical Analysis and Interpretation, Plymouth Marine Laboratory, Plymouth.

Da Costa R.M. and Fernández F., 2002. Feeding and survival rates of the copepods Euterpina acutifrons Dana and Acartia grani Sars on the dinoflagellates Alexandrium minutum Balech and Gyrodinium corsicum Paulmier and the Chryptophyta Rhodomonas baltica Karsten. J. Exp. Mar. Biol. Ecol., 273, 131-142.

Da Costa R.M., Franco J., Cacho E. and Fernández F., 2005. Toxin content and toxic effects of the dinoflagellate Gyrodinium corsicum (Paulmier) on the ingestion and survival rates of the copepods Acartia grani and Euterpina acutifrons. J. Exp. Mar. Biol. Ecol., 322, 177-183.

Dai Z. and Liu J.T., 2013. Impacts of large dams on downstream fluvial sedimentation: an example of the Three Gorges Dam (TGD) on the Changjiang (Yangtze River). J. Hydrol., 480, $10-18$.

Dai Z., Liu J.T., Wei W. and Chen J., 2014. Detection of the Three Gorges Dam influence on the Changjiang (Yangtze River) submerged delta. Sci. Rep., 4, 1-7.

Dhivert E., Grosbois C., Coynel A., Lefèvre I. and Desmet M., 2015. Influences of major flood sediment inputs on sedimentary and geochemical signals archived in a reservoir core (Upper Loire Basin, France). Catena, 126, 75-85.

Díaz-Pardo E., Vazquez G. and López-López E., 1998. The phytoplankton community as a bioindicator of health conditions of Atezca Lake, Mexico. Aquat. Ecosyst. Health Manag., 1, 257-266.

Domingues R.B., Barbosa A.B. and Galvão H.M., 2014. River damming leads to decreased phytoplankton biomass and disappearance of cyanobacteria blooms. Est. Coast. Shelf Sci., 136, 129-138.

El Bastawesy M., Gabr S. and Mohamed I., 2014. Assessment of hydrological changes in the Nile River due to the construction of Renaissance Dam in Ethiopia. Egypt. J. Remote Sens. Space Sci., 18, 65-75.

Feng L., Hu C., Chen X. and Song Q., 2014. Influence of the Three Gorges Dam on total suspended matters in the Yangtze Estuary and its adjacent coastal waters: observations from MODIS. Remote Sens. Environ., 140, 779-788.

Friedl G. and Wüest A., 2002. Disrupting biogeochemical cycles - consequences of damming. Aquat. Sci., 64, 55-65.

Fu M., Wang Z., Li Y., Li R., Sun P., Wei X., Lin X. and Guo J., 2009. Phytoplankton biomass size structure and its regulation in the Southern Yellow Sea (China): seasonal variability. Cont. Shelf Res., 29, 2178-2194.

Gao X. and Song J., 2005. Phytoplankton distributions and their relationship with the environment in the Changjiang Estuary, China. Mar. Pollut. Bull., 50, 327-335. 
Grasshoff K., Kremling K. and Manfred E., 1999. Methods of Seawater Analysis, Wiley- VCH, New York, 600 p.

Guerrero F. and Rodriguez V., 1998. Existence and significance of Acartia grani resting eggs (Copepoda: Calanoida) in sediments of a coastal station in the Alboran Sea (SE Spain). J. Plankton Res., 20, 305-314.

Haghighi A.T., Marttila H. and Kløve B., 2014. Development of a new index to assess river regime impacts after dam construction. Glob. Planet Change, 122, 186-196.

Hallegraeff G.M., 1993. A review of harmful algal blooms and their apparent global increase. Phycology, 32, 79-99.

Humborg C., Ittekkot V., Cociasu A. and Bodungen B., 1997. Effect of Danube River dam on Black Sea biogeochemistry and ecosystem structure. Nature, 386, 385-388.

Jiang Z., Liu J., Chen J., Chen Q., Yan X., Xuan J. and Zeng J., 2014. Responses of summer phytoplankton community to drastic environmental changes in the Changjiang (Yangtze River) estuary during the past 50 years. Water Res., 54, 1-11.

Jiang Z., Chen J., Zhou F., Shou L., Chen Q., Tao B., Yan X. and Wang K., 2015. Controlling factors of summer phytoplankton community in the Changjiang (Yangtze River) Estuary and adjacent East China Sea shelf. Cont. Shelf Res., $101,71-84$.

Klausmeier C.A., Litchman E., Daufresne T. and Levin S., 2008. Phytoplankton stoichiometry. Ecol. Res., 23, 479-485.

Kummu M. and Varis O., 2007. Sediment-related impacts due to upstream reservoir trapping, the lower Mekong River. Geomorphology, 85, 275-293.

Lam-Hoai T., Guiral D. and Rougier C., 2006. Seasonal change of community structure and size spectra of zooplankton in the Kaw River estuary (French Guiana). Est. Coast. Shelf Sci., 68, 47-61.

Li H., Tang H., Shi X., Zhang C. and Wang X., 2014. Increased nutrient loads from the Changjiang (Yangtze) River have led to increased harmful algal blooms. Harmful Algae, 39, 92-101.

Li X.Y., Dong S.K., Zhao Q.H. and Liu S.L., 2010. Impacts of Manwan Dam construction on aquatic habitat and community in middle reach of Lancang River. Proc. Environ. Sci., 2, $706-712$.

Liu L., Zhou J., Zheng B., Cai W., Lin K. and Tang J., 2013. Temporal and spatial distribution of red tide outbreaks in the Yangtze River estuary and adjacent waters, China. Mar. Pollut. Bull., 72, 213-221.

Lü X.G., Qiao F.L., Xia C.S., Zhu J.R. and Yuan Y.L., 2006. Upwelling off Yangtze River estuary in summer. J. Geophys. Res., 111, 1-19.

McQuoid M.R., Godhe A. and Nordberg K., 2002. Viability of phytoplankton resting stages in the sediments of a coastal Swedish fjord. Eur. J. Phycol., 37, 191-201.

Milliman J.D., 1997. Blessed dams or damned dams? Nature, 386, 325-327.

Morais P., Chícharo M.A. and Chícharo L., 2009. Changes in a temperate estuary during the filling of the biggest European dam. Sci. Total Environ., 407, 2245-2259.
Ning X., Shi J., Cai Y. and Liu C., 2004. Biological productivity front in the Changjiang estuary and the Hangzhou Bay and its ecological effects. Acta Oceanol. Sin., 26, 96-106 (in Chinese).

Priddle J. and Fryxell G., 1985. Handbook of the Common Plankton Diatoms of the Southern Ocean, British Antarctic Survey, Cambridge.

$\mathrm{Pu} \mathrm{X.,} \mathrm{Wu} \mathrm{Y.} \mathrm{and} \mathrm{Zhang} \mathrm{Y.,} \mathrm{2001.} \mathrm{Nutrient} \mathrm{limitation} \mathrm{of}$ phytoplankton in the Changjiang estuary: condition of nutrient limitation in spring. Acta Oceanol. Sin., 23, 57-65.

Shen H. and Hong J., 1994. Investigation report on the skeletonema costatum red tide in Changjing River Estuarystudy on the phytoplankton community composition and cell morphology. Oceanol. Limnol. Sin., 25, 591-595 (in Chinese).

Shen H.T., 2001. Material Flux of the Changiiang Estuary, Ocean Press, Beijing (in Chinese).

Smayda T.J., 1997. Harmful algal blooms: their ecophysiology and general relevance to phytoplankton blooms in the sea. Limnol. Oceanogr., 42, 1137-1153.

State Oceanic Administration, 1991. Specifications for Oceanographic Survey, Standards Press of China, Beijing (in Chinese).

Tomas C.R., 1997. Identifying Marine Phytoplankton, Academic Press, San Diego.

Turley C.M., 1999. The changing Mediterranean Sea - a sensitive ecosystem? Prog. Oceanogr., 44, 387-400.

Utermöhl H., 1958. Zur Vervollkommung der quantitativen Phytoplankton-Methodik. Int. Ver. Theor. Angew. Limnol., 9, 1-38.

Verity P.G., 2010. Expansion of potentially harmful algal taxa in a Georgia Estuary (USA). Harmful Algae, 9, 144-152.

Wang J.H., 2002. HAB alga nearby Changjiang Estuary. Mar. Environ. Sci., 21, 37-41.

Xu Y., Cai Q., Ye L., Zhou S. and Han X., 2009. Spring diatom blooming phases in a representative eutrophic bay of the Three-Gorges Reservoir, China. J. Freshwat. Ecol., 24, 191-198.

Zhang J., Yu Z.G., Liu S.M., Xu H. and Liu M.G., 1997. Dynamics of nutrient elements in three estuaries of North China: the Luanhe, Shuangtaizihe and Yalujiang. Estuaries, 20, 110-123.

Zhao Q., Liu S. and Dong S., 2010. Effect of dam construction on spatial-temporal change of land use: a case study of Manwan, Lancang River, Yunnan, China. Proc. Environ. Sci., 2, 852-858.

Zhao Y., Yu Z., Song X. and Cao X., 2009. Biochemical compositions of two dominant bloom-forming species isolated from the Yangtze River Estuary in response to different nutrient conditions. J. Exp. Mar. Biol. Ecol., 368, 30-36.

Zhou M., Shen Z. and Yu R., 2008. Responses of a coastal phytoplankton community to increased nutrient input from the Changjiang (Yangtze) River. Cont. Shelf Res., 28, $1483-1489$. 
Appendix 1. Phytoplankton species found in the YRE and adjacent sea areas in 2010-2011.

\begin{tabular}{|c|c|c|}
\hline Species & Species & Species \\
\hline Bacillariophyta & Chaetoceros paradoxus & Protoperidinium conicum \\
\hline Coscinodiscus centralis & Coscinodiscus excentricus & Ceratium sp. \\
\hline Odontella sinensis & Pseudo-nitzschia $\mathrm{sp}$. & Prorocentrium sp. \\
\hline Stephanopyxis palmeriana & Chaetoceros pseudocurvisetus & Heterocapsa sp. \\
\hline Thalassiothrix longissima & Melosira nummuloides & Noctiluca scintillans \\
\hline Coscinodiscus concinnus & Planktoniella formosa & Pyrocystis noctiluca \\
\hline Skeletonema costatum & Chaetoceros lorenzianus & Cochlodinium sp. \\
\hline Chaetoceros affinis & Thalassionema nitzschioides & Alexandrium sp. \\
\hline Chaetoceros distans & Nitzschia sp. & Ceratium lineatum \\
\hline Pinnularia sp. & Chaetoceros castracanei & Pyrophacus steinii \\
\hline Coscinodiscus sp. & Paralia sulcata & Ornithocercus steinii \\
\hline Coscinodiscus bipartitus & Melosira sulcata & Ceratium tripos \\
\hline Coscinodiscus spinosus & Chaetoceros sp. & Ceratium trichoceros \\
\hline Rhizosolenia alata f. indica & Pseudo-nitzschia pungens & Protoperidinium subinerme \\
\hline Chaetoceros curvisetus & Odontella mobiliensis & Karenia mikimotoi \\
\hline Coscinodiscus asteromphalus & Coscinodiscus oculus-iridis & Gymnodinium sp. \\
\hline Cyclotella sp. & Thalassiosira sp. & Dinophysis caudata \\
\hline Pleurosigma sp. & Rhizosolenia setigera & Prorocentrum dentatum \\
\hline Chaetoceros siamense & Actinocyclus sp. & Dinophysis acuminata \\
\hline Coscinodiscus subtilis & Eucampia zoodiacus & Protoperidinium pallidum \\
\hline Guinardia flaccida & Thalassionema frauenfeldii & Protoperidinium oceanicum \\
\hline Bacteriastrum hyalinum & Triceratium favus & Ceratium fusus \\
\hline Coscinodiscus thorii & Fragilariopsis sp. & Protoceratium sp. \\
\hline Chaetoceros didymus f. protuberans & Ditylum brightwellii & Ceratium breve \\
\hline Chaetoceros didymus & Chaetoceros decipiens & Ceratium furca \\
\hline Chaetoceros dipyrenops & Chaetoceros compressus & Protoperidinium depressum \\
\hline Coscinodiscus argus & Rhizosolenia styliformis & Pyrophacus sp. \\
\hline Pseudo-nitzschia delicatissima & Chaetoceros peruvianus & Ceratium schmidti \\
\hline Chaetoceros debilis & Pseudosolenia calcar-avis & Cyanophyta \\
\hline Guinardia delicatula & Rhizosolenia stolterforthii & Lyngbya sp. \\
\hline Coscinodiscus jonesianus & Coscinodiscus gigas & Oscillatoria sp. \\
\hline Thalassiosira nordenskioldi & Chaetoceros subtilis & Chrysophyta \\
\hline Streptotheca thamesis & Dinophyta & Dictyocha fibula \\
\hline
\end{tabular}

